\title{
Penerapan Rule Based Dengan Algoritma Viterbi Untuk Deteksi Kesalahan Huruf Kapital Pada Karya Ilmiah
}

\author{
Reza Juanda', Ilman Zuhri Yadi*2 \\ 1,2Informatics Departement, Universitas Bina Darma, Palembang, Indonesia \\ Email: rebela0406@gmail.com² ${ }^{1}$ ilmanzuhriyadi@binadarma.ac.id ${ }^{2}$
}

\begin{abstract}
The use of capital letters is one element of the grammar of the Indonesian Spelling General Guidelines (PUEBI). According to the Large Indonesian Language Dictionary (KBBI), capital letters are letters of a special size and shape (larger than ordinary letters), usually used as the first letter of the first word in a sentence, the first letter of the name itself, and so on. The use of capital letters in a paper is required. However, the ability to use letters of public capital still tends to be not so good. The problem is writing that has not followed the Indonesian Spelling General Guidelines (PUEBI) rules. Settlement steps on how to implement an Indonesian Spelling General Guidelines (PUEBI) rule into software. Therefore, the author will try to make a software that can automatically detect if there are errors in writing according to the rules of general Indonesian spelling guidelines (PUEBI) on documents, journals, bibliography and scientific works.
\end{abstract}

Keywords: capital letters, Scientific Manusripts, PUEBI

\section{PENDAHULUAN}

Secara garis besar, bahasa dapat diartikan sebagai sistem bunyi yang memiliki makna, lambang bunyi, dan dituturkan dari manusia dalam situasi yang wajar yang digunakan sebagai alat komunikasi (Yendra, 2016). Sebagai sebuah sistem, bahasa terbentuk oleh sebuah aturan, yang tersusun dalam Pedoman Umum Ejaan Bahasa Indonesia (PUEBI). Pedoman Umum Ejaan Bahasa Indonesia (PUEBI) adalah suatu aturan penulisan pedoman umum ejaan bahasa Indonesia yang berlaku sejak tahun (2015) berdasarkan Peraturan Kementerian Pendidikan dan Kebudayaan Republik Indonesia (Nomor 50 Tahun 2015). Ejaan ini menggantikan ejaan yang disempurnakan (EYD). Badan Pengembangan dan Pembinaan Bahasa, (2015). 
Vol. 1, No. 1, January 2020 e-ISSN: 2775-2496

https://journal-computing.org/index.php/journal-cisa/index

Penggunaan huruf kapital merupakan salah satu elemen dari tata bahasa Pedoman Umum Ejaan Bahasa Indonesia (PUEBI). Menurut Kamus Besar Bahasa Indonesia (KBBI), huruf kapital adalah huruf yang berukuran dan berbentuk khusus (lebih besar dari huruf biasa), biasanya digunakan sebagai huruf pertama dari kata pertama dalam sebuah kalimat, huruf pertama nama diri, dan sebagainya. Penggunaan huruf kapital dalam sebuah karya tulis diperlukan. Namun, kemampuan menggunakan huruf kapital masyarakat masih cenderung belum begitu baik.

Seperti hasil penelitian nilai rata-rata kemampuan ejaan dan teknik penulisan huruf kapital dalam kalimat oleh mahasiswa hanya 6,60\% (Dhimas Asih Kusuma Persadha, 2016). Dan ada lagi penelitian sebelumnya juga pernah dilakukan dimana penelitian dilakukan untuk memeriksa huruf kapital dan tanda baca dari teks yang diucapkan secara langsung pada bahasa siaran berita dalam bahasa Portugis dan bahasa Inggris (Batista et al, 2012). Dan terdapat juga penelitian pemeriksaan huruf kapital dimana aplikasi yang dibuat berupa pengoreksian huruf kapital pada teks bahasa Indonesia dengan menggunakan kamus data, hasilnya dapat mendeteksi huruf kapital dengan Algoritma Viterbi (Saputra et al, 2015).

Oleh karena itu maka penulis akan mencoba menggunakan Algoritma Viterbi untuk membantu dalam melakukan pengoreksian dibutuhkan suatu perangkat lunak yang dapat secara otomatis mendeteksi apabila ada kesalahan dalam penulisan sesuai aturan pedoman umum ejaan bahasa indonesia (PUEBI) pada dokumen, jurnal, daftar pustaka dan karya ilmiah. Menurut Andrew J. Viterbi (1967) Algoritma Viterbi pada mulanya digunakan untuk menyelesaikan masalah pengkodean yang rumit, namun akhir-akhir ini algoritma viterbi banyak digunakan untuk mempermudah penyelesaian masalah pada bidang-bidang lain. Salah satunya adalah digunakan dalam Hidden Markov Model (HMM). Algoritma viterbi merupakan algoritma dynamic programming untuk menemukan barisan hidden state yang paling maksimal dari suatu barisan observasi.

\section{METODOLOGI PENELITIAN}

\subsection{Rule Based}

Menurut Lusiani dan Cahyono (2016). Rule Based adalah sistem berbasis aturan suatu perangkat lunak yang menyajikan keahlian pakar dalam bentuk aturan-aturan pada suatu domain tertentu untuk menyelesaikan 
Vol. 1, No. 1, January 2020 e-ISSN: 2775-2496

https://journal-computing.org/index.php/journal-cisa/index

suatu permasalahan. Rule Based model sederhana yang bisa diadaptasi ke banyak masalah. Namun, jika aturan terlalu banyak, pemeliharaan sistem akan rumit dan terdapat kesalahan dalam kerjanya. Teori Rule Based ini menggunakan teknik yang sederhana, dimulai dengan dasar aturan yang berisi semuan pengetahuan dari permasalahan yang dihadapi yang kemudian dikodekan ke dalam aturan if-then yang mengandung data, pernyataan dan informasih awal. Sistem akan ditemuka, maka sistem akan melakukan kondisi then. Perulangan ini akan terus berlanjur hingga salah satu atau dua kondisi bertemu, jika aturan tidak diketemukan maka sistem tersebut harus keluar dari perulangan (terminate).

\subsection{Perangkat Lunak (Software)}

Menurut Rosa Dan Shalahuddin (2013). Perangkat lunak (Software) adalah program komputer yang berasosiasi dengan dokumentasi perangkat lunak seperti dokumentasi kebutuhan, model desain, dan cara penggunaan (user manual). Sebuah program komputer tanpa terasosiasi dengan dokumentasi maka belum dapat disebut dengan perangkat lunak (software). Sebuat perangkat lunak sering disebut denga sistem perangkat lunak. Sistem berarti kumpulan komponen yang saling terkait dan mempunyai satu tujuan yang ingin dicapai. Sistem perangkat lunak berarti sebuah sistem yang memiliki komponen berupa perangkat lunak yang memiiki hubungan satu sama lain untuk memenuhi kebutuhan pelanggan (customer). Pelanggan (customer) adalah orang atau organisasi yang memesan atau membeli perangkat lunak (software) dari pengembang perangkat lunak atau bisa dianggap bahwa pelanggan (customer) adalah orang atau organisasi yang sukarela mengeluarkan uang untuk memesan atau membeli perangkat lunak. User atau pemakai perangkat lunak adalah orang yang memiliki kepentingan untuk memakai atau menggunakan perangkat lunak untuk memudahakan pekerjaannya. Menurut Melwin (2007). Mendefinisikan perangkat lunak sebagai berikut: Berfungsi sebagai pengatur aktivitas kerja komputer dan semua intruksi yang mengarah pada sistem komputer. Perangkat lunak menjembatani interaksi user dengan komputer yang hanya memahami bahasa mesin. Software dibangun berdasarkan permintaan atau kebutuhan penggunanya Ini sangat jelas pada software aplikasi. Jadi

Perangkat lunak adalah Perintah (program komputer) yang bila 
Vol. 1, No. 1, January 2020 e-ISSN: 2775-2496

https://journal-computing.org/index.php/journal-cisa/index

dieksekusi memberikan fungsi dan unjuk kerja seperti yang diinginkan. Struktur data yang memungkinkan program memanipulasi informasi secara proporsional, dan dokumen yang menggambarkan operasi dan kegunaan program.

\subsection{Huruf Kapital}

Menurut Cauchy Murtopo (2016). Huruf kapital adalah huruf pertama kata pada awal kalimat langsung dan sebagai huruf pertama nama gelar kehormatan, keturunan dan keagamaan dan diikuti nama orang.

\subsection{Algoritma Viterbi}

Menurut Andrew J. Viterbi (1967). Algoritma Viterbi pada mulanya digunakan untuk menyelesaikan masalah pengkodean yang rumit, namun akhir-akhir ini algoritma viterbi banyak digunakan untuk mempermudah penyelesaian masalah pada bidang-bidang lain. Salah satunya adalah digunakan dalam Hidden Markov Model (HMM). Algoritma viterbi merupakan algoritma dynamic programming untuk menemukan barisan hidden state yang paling maksimal dari suatu barisan observasi.

\subsection{Langkah-Langkah Algoritma Viterbi}

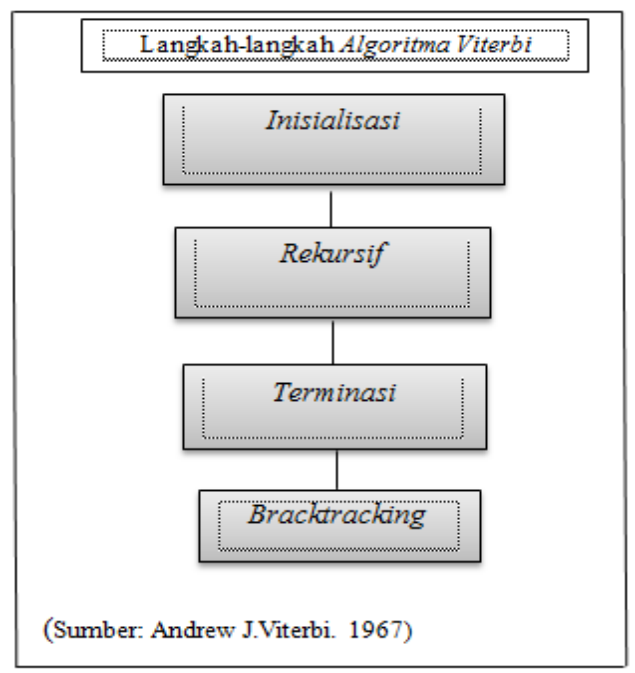

Gambar 1. Langkah-Langkah Algoritma Viterbi

1) Inisialisasi adalah tugas pemberian nilai awal yang dilakukan saat deklarasi variabel atau obyek. 
Vol. 1, No. 1, January 2020 e-ISSN: 2775-2496

https://journal-computing.org/index.php/journal-cisa/index

2) Rekursifadalah fungsi yang memanggil dirinya sendiri secara langsung ataupun tidak, dan proses pemanggilannya itu disebut rekursif. Masalah yang dapat diselesaikan secara rekursif adalah masalah yang dibagi menjadi satu atau lebih masalah-masalah serupa yang lebih kecil.

3) Terminasi adalah intruksi yang dilakukan setelah pengulangan selesai dilaksanakan.

4) Runut-balik (backtracking) adalah berbasis pada DFS untuk mencari solusi persoalan secara lebih mangkus. Runut-balik, yang merupakan perbaikan dari brute-force, secara sistematis mencari solusi yang ada.

\subsection{Pseudocode Algoritma Viterbi}

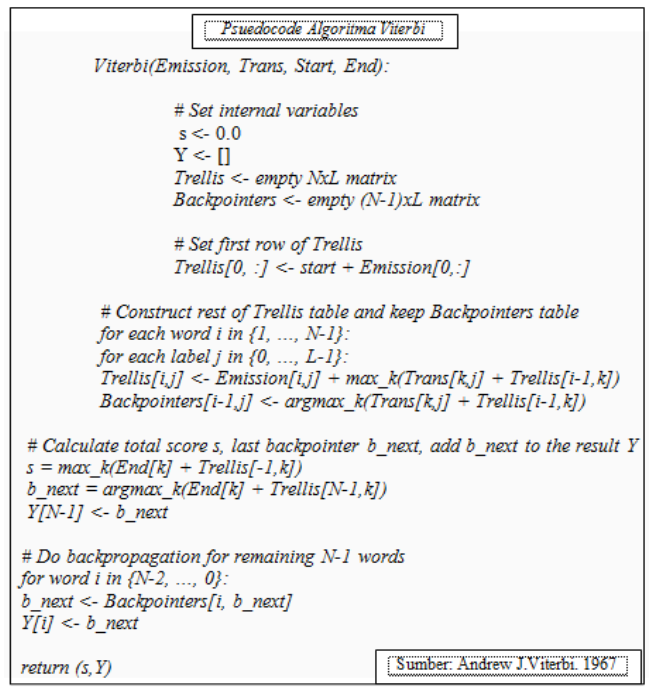

Gambar 2. Pseudocode Algoritma Viterbi

Algoritma mengambil 2 matriks dan 2 vektor sebagai input:

a. Emisi adalah matriks NxL yang menyimpan log-probabilitas untuk mengamati kata $n$, diberi label 1

$$
\mathrm{P}(\mathrm{n} \mid 1)=\operatorname{misi}[\mathrm{n}, 1]
$$

b. Trans adalah matriks LxL yang menyimpan log-probabilitas transisi dari label sebelumnya (Yp) ke label saat ini (Yc)

$\mathrm{P}(\mathrm{Yc} \mid \mathrm{Yp})=$ 
Vol. 1, No. 1, January 2020 e-ISSN: 2775-2496

https://journal-computing.org/index.php/journal-cisa/index

c. Start adalah vektor Lx1 yang menyimpan log-probabilitas transisi dari awal kalimat $<$ s $>$ untuk setiap label 1

$$
\mathrm{P}(1 \mid<\mathrm{s}>)=
$$

d. End adalah vektor Lx1 yang menyimpan log-probability transisi dari label l dari kata terakhir ke akhir kalimat $</$ s $>$

$$
\mathrm{P}(</ \mathrm{s}>\mid 1)=
$$

Secara internal, teralis matriks NxL [i, l] menyimpan skor urutan terbaik dari 1 ... i sedemikian rupa sehingga li $=1$. Matriks backpointers $(\mathrm{N}-1) \mathrm{xL}$ melacak dari mana sebelumnya label skor optimal yang dihitung untuk setiap sel berasal. Perhatikan bahwa backpointers memiliki satu baris kurang dari Teralis karena backpointer terakhir dapat disimpan dalam variabel tunggal (b_next), sebelum memulai backpropagation.

\subsection{Flowchart Algoritma Viterbi}

Diagram Flowchart ini berfungsi untuk mendesain dan merepresentasikan program. Sebelum pembuatan program, tujuannya ialah mempermudah programmer dalam menentukan alur logika program yang akan dibuat. Sesudah pembuatan program fungsinya adalah untuk menjelaskan alur program kepada orang lain atau user.

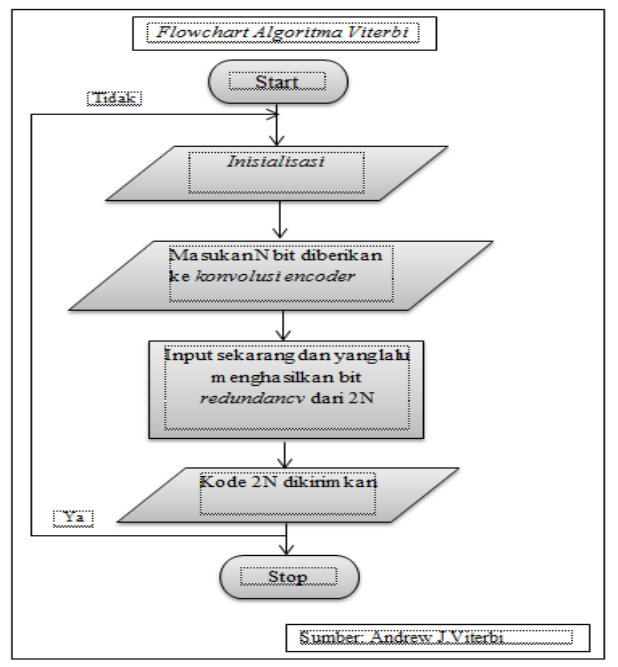

Gambar 3. Flowchart Algoritma Viterbi 


\subsection{Penerapan}

Menurut Wahab dalam Van Meter dan Van Horn (2008). Penerapan adalah merupakan tindakan-tindakan yang dilakukan baik oleh individuindividu atau kelompok-kelompok yang diarahkan pada tercapainya tujuan yang telah digariskan dalam keputusan.

\subsection{Deteksi}

Menurut Titatjahya (2014). Deteksi adalah suatu proses untuk memeriksa atau melakukan pemeriksaan terhadap sesuatu dengan menggunakan cara dan teknik tertentu. Deteksi dapat digunakan untuk berbagai masalah, misalnya dalam sistem pendeteksi memecahkan suatu masalah dengan berbagai cara tergantung metode yang diterapkan sehingga menghasilkan sebuah solusi.

\section{HASIL DAN PEMBAHASAN}

Metode pendekteksian dengan menggunakan Algoritma Viterbi diterapkan dalam membangun Perangkat lunak deteksi dan dapat mengatasi kesalahan penggunaan huruf kapital pada kalimat di dokumen. Hasil dari perangkat lunak ini akan digunakan untuk mendeteksi sebuah kata pada kalimat di dokumen. Berikut dibutuhkan perangkat keras (Hardware) dan perangkat lunak (Software).

1. Perangkat Keras (Hardware), Spesifikasi perangkat keras yang digunakan dalam membuat Sistem keamana database pada sistem Informasi Dinas Pendidikan Provinsi Sumatera Selatan sebagai berikut:

a. Intel ${ }^{\circledR}$ core $^{\mathrm{TM}}$ Processor i3-4005U

b. HDD $500 \mathrm{~GB}$

c. Memory $2 \mathrm{~GB}$

2. Perangkat Lunak (Software), Adapun beberapan Software yang dibutuhkan untuk membuat sistem keamanan database pada Sistem Informasi Dinas Pendidikan Provinsi Sumatera Selatan adalah sebagai berikut:

a. Operating System Windows 8.1

b. Microsoft Office Word 
Vol. 1, No. 1, January 2020 e-ISSN: 2775-2496

https://journal-computing.org/index.php/journal-cisa/index

c. MySQL

d. Hypertext Preprocessor (PHP)

e. Xampp

f. Microsoft Visio

\section{1) Pengujian Upload Dokumen}

Pengujian pertama berupa upload dokumen dan kemudian klik open.

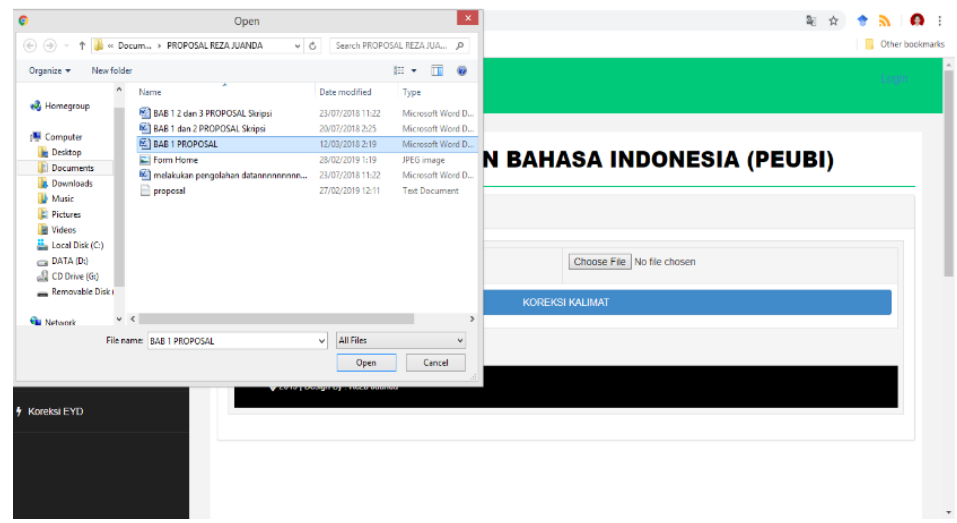

Gambar 4 Pengujian Upload Dokumen

\section{2) Pengujian Tambah Kata}

Pengujian kedua berupa tuliskan kalimat, tambahkan keterangan pada kolom keterangan terus klik cek kata pada database terus klik select all terus kemudian tambah kata baru ke database dan akan muncul notif berhasil ditambahkan kedalam database.

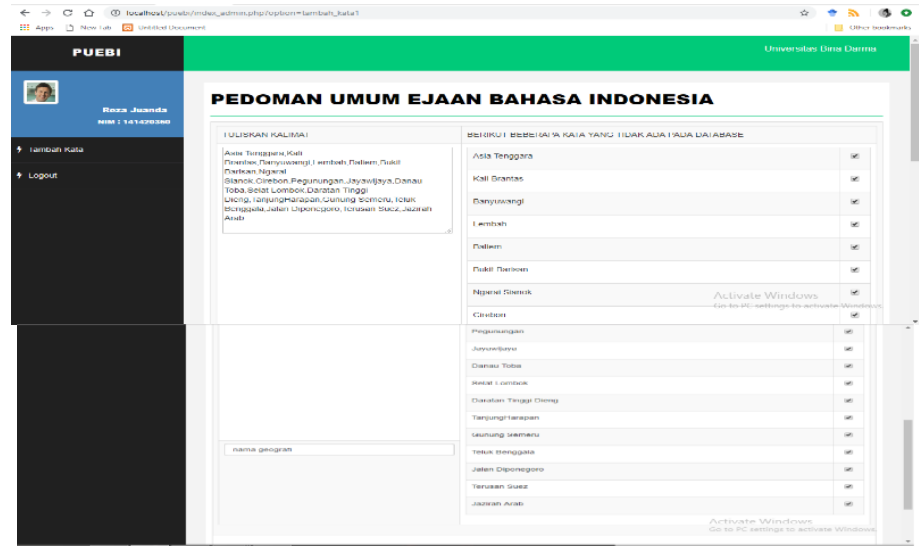

Gambar 5 Pengujian Tambah Kata 
Vol. 1, No. 1, January 2020 e-ISSN: 2775-2496

https://journal-computing.org/index.php/journal-cisa/index

\section{KESIMPULAN}

Berdasarkan hasil dan pembahasan yang membahas tentang penerapan Rule Based dengan Algoritma Viterbi untuk deteksi kesalahan penggunaan huruf kapital pada karya pada bab sebelumnya, penulis mendapatkan beberapa kesimpulan sebagai berikut:

1) Mempermudah mengetahui kesalahan penggunaan huruf kapital pada sebuah kalimat di dokumen.

2) Algoritma Viterbi dapat diimplementasikan untuk perulangan perkata didalam perangkat lunak yang dibuat sehingga mendapatkan hasil kata yang sempurna.

3) Teratasinya keraguan dalam meletakan huruf kapital pada kalimat di dokumen.

4) Sistem pendeteksi ini dapat diimplementasikan pada aplikasi dengan menggunakan bahasa pemrograman Hypertext Prepocessor (PHP) dan database Mysql.

\section{DAFTAR PUSTAKA}

[1] Ahmad Rifaldi. 2017. Sistem Deteksi Dan Estimasi Jarak Lubang Pada Pedestrian Dengan Teknik Pengolahan Citra Menggunakan Mono Kamera. Dokumen Karya Ilmiah Program Studi Departemen Teknik Informatika Fakultas Teknik Informasi Universitas Hasanuddin Makasar.

[2] Annisasukm. Penerapan Diakses Dari https://elib.unikom.ac.id/files/disk1/547/jbptunikompp-gdlannisasukm-27305-2-babii.pdf pada tanggal 2 juni 2008.

[3] Dimas Asih Kusuma Persahda . 2016. Studi Kompetensi Kemampuan Menulis Dikalangan Mahasiswa. Dokumen Karya Ilmiah. Program Studi Sastra Bahasa Indonesia Fakultas Sastra Universitas Malang.

[4] Dwiloka, Bambang Dan Riana, Rati. 2017. Teknik Menulis Karya Ilmiah.Rineka Cipta Semarang.

[5] Hilari Larasati Dan Siti Masripah. 2017. Analisa Dan Perancangan Sistem Informasi Pembelian GRC Dengan Metode Waterfall. Dokumen Karya Ilmiah. Program Studi Tenik Informatika. Fakultas Ilmu Komputer, Universitas AMIK BSI Jakarta.

[7] Ima Nurhidayah. 2016. Analisa Kesalahan Penggunaan Huruf Kapital Dan Pemilihan Kata Pada Karangan Deskripsi Siswa Kelas VIII Smp Nu I Indonesia. Fakultas Keguruan Dan Ilmu Pendidikan . Universitas Muhammadiyah Sukarta. 
Vol. 1, No. 1, January 2020 e-ISSN: 2775-2496

https://journal-computing.org/index.php/journal-cisa/index

[8] Kustiyahningsih, Yeni Dan Amanisa, Rose Devie. 2010. Pemograman Basis Data Berbasis Web Menggunakan PHP Dan MySQL. Graha Ilmu. Yogyakarta.

[9] Ony Naratulita Maringga.2018. Pemeriksaan Penggunaan Huruf Kapital Pada Teks Bahasa Indonesia Menggunakan Metode Rule Based. Dokumen Karya Ilmiah. Program Studi Teknologi Informasi. Fakultas Ilmu Komputer Dan Teknologi Informasi. Universitas Sumatera Utara Medan

[10] Retno Megasafitri Dan Wahyu Sukartiningsih. 2018. Pengembangan Media Interaktif Berbasis Adobe Flash Dalam Pembelajaran Menulis Ekosisi Pada Siswa Kelas V. Dokumen Karya Ilmiah. PGSD FIP. Universitas Surabaya. Skripsi Hal 1781.

[11] Rezki Syaputra Dan Rachmansyah. 2018. Analisis Sentimen Pada Sosial Media Twitter Terhadap Politik Di Indonesia Menggunakan Text Mining Dengan Metode Naive Boyes Classfire. Dokumen Karya Ilmiah. Program Studi Teknik Informatika. Fakultas Ilmu Komputer. STMIK GI MDP. Sumatera Selatan Palembang.

[12] Reofanandr. Perangkat Lunak. Diakses Dari https://elib.unikom.ac.id/files/disk1/491/jbptunikompp-gdlreofanandr-24508-4-babii.pdf pada tanggal 5 juni 2015.

[13] Suco Sinaga. 2014. Perancangan Sistem Informasi Pembayaran SPP Pada SMA Negeri 23 Kabupaten Tanggerang. Dokumen Karya Ilmiah. Program Studi Sistem Informasi. Fakultas Ilmu Komputer. Universitas RAHARJA Tanggerang.

[14] Triswan. Pengenalan PHP. Diakses Dari https://ilmukomputer.org/wpcontent/uploads/2009/03/triswan-pengenalanphp.pdf pada tanggal 3 maret 2003.

[15] Wahana Komputer. 2010. Panduan Belajar MySQL Database Server. Media Kita Jakarta Selatan.

[16] Yuliaanitre. Metode Prototyping . Diakses Dari https://elib.unikom.ac.id/files/disk1/536/jbptunikompp-gdlyulianitre26769-7-unikom__y-i.pdf pada tanggal November 2015.

[17] Yakub. 2008. Sistem Basis Data Tutorial Konseptual. Gava Media Graha Ilmu. Yogyakarta.

[18] Ziyan Farid. 2015. Aplikasi Algoritma Viterbi Dalam Hidden Markov Model Untuk Menganalisi Tren Pasar Saham Bursa Efek. Dokumen Karya Ilmiah. Program Studi Matematika. Fakultas Sains Dan Teknologi. Universitas Islam Negeri Maulana Malik Ibrahim Malang. 